\title{
ВНЕШНЕЭКОНОМИЧЕСКАЯ ДЕЯТЕЛЬНОСТЬ
}

М. И. Масленников ${ }^{\text {a) }}$

а) Институт экономики УрО РАН

\section{ПРИОРИТЕТЫ РАЗВИТИЯ ВНЕШНЕЭКОНОМИЧЕСКИХ СВЯЗЕЙ РЕГИОНОВ УРАЛА СО СТРАНАМИ БРИКС}

В статье анализируются терминологический аппарат БРИКС, региональные тенденции развития бизнеса и мера его участия во внешнеэкономической деятельности данной группы стран, выявляется вклад различных секторов внешнеэкономической деятельности регионов в развитие экономики, анализируются показатели, отображающие уровень развития внешнеэкономических связей, выявляются альтернативные варианты развития внешней торговли, издержки и выгоды от ее переориентации, а также причины низких показателей развития внешнеторговой деятельности регионов Урала со странами БРИКС, предлагаются меры по их совершенствованию и развитию, исследуются механизм и инструментарий стимулирования развития внешнеэкономических связей регионов со странами БРИКС, исследуются внутренние и внешние мотивы и стимулы расширения этих связей, а также факторы, влияющие на формирование региональных рынков, с отображением разнонаправленных тенденций в деятельности бизнеса, правительства, общества по развитию внешнеэкономических связей регионов Урала со странами БРИКС, и прежде всего с Бразилией, Индией, Китаем и Южно-Африканской Республикой, отображаются экспортно-импортные особенности внешнеторговых операций с этими странами, а также возможные пути и направления расширения горизонта прогностики внешнеэкономических связей в условиях ужесточения и ограничения аналогичных операций и финансовых источников со стороны развитых стран, прежде всего США и стран EC. Автор делает попытки отобразить возможные сценарии, проблемы и трудности для страны и регионов Урала переориентации внешнеэкономических связей со стран Западной Европы на страны Юго-Восточной Азии, а также реальные возможности участия регионов страны в импортозамещении и развитии собственной ресурсной и производственной базы. Основной упор в исследовании делается на анализ внешнеэкономических связей предприятий Среднего Урала со странами БРИКС, выявлении причин и следствий для предприятий старопромышленного региона сокращения экспортно-импортных операций как на развитых, так и развивающихся рынках в условиях ужесточения и нестабильности конъюнктуры на отечественном и мировом финансовых рынках.

Ключевые слова: БРИКС, внешнеэкономические связи, Россия, регионы Урала

\section{Введение}

Процессы интернационализации и глобализации охватывают все новые регионы и сферы деятельности порой в весьма необычных формах и проявлениях. В последние годы в дополнение к традиционным интеграционным группировкам развитых стран (НАФТА, EACT, EC) и разного рода объединениям и зонам развивающихся стран (ШОС, АТЭС, СНГ, ЕАЭС, ОДКБ, МЕРКОСУР и т. д.) стали появ-

\footnotetext{
${ }^{1}$ () Масленников М. И. Текст. 2015.
}

ляться новые акронимы для обозначения потенциальных лидеров мировой экономики: в 1950-е гг. - ЕОУС, Евроатом, в 1957 г. - ЕЭС, в 1960-1970-е гг. - ОПЕК, ОЭСР, НИС (новые индустриализирующиеся государства - Южная Корея, Тайвань, Гонконг, Сингапур) [1, с. 86, 98, $177,205,228,395]$, в 2000-е гг. - БРИКС, на горизонте выкристаллизовываются и другие, например, MIST (Мексика, Индонезия, Южная Корея, Турция) и Транстихоокеанское партнерство (ТТП в составе 12 стран), создаваемое США в закрытом режиме с 2005 г. в противовес АТЭС, без включения в него России и Китая. 
В этой связи возрастает теоретический и практический интерес к анализу новых явлений в мировой и отечественной экономике, расширяются возможности использования зарубежного приемлемого опыта формирования интеграционных группировок нового типа.

\section{Понятийный аппарат БРИКС}

В 2001 г. сотрудник банка «Голдмен Сакс» (Goldman Sachs, USA) экономист Джим О’Нил (Jim O’Neill) ввел термин БРИК (по-английски brick - кирпич), объединив в аббревиатуру первые заглавные буквы названий стран Бразилия, Россия, Индия и Китай (BRIC), которые в 2000-е гг. относились к основным и быстро растущим экономикам мира. Эти страны привлекли внимание ведущих финансовых и инвестиционных компаний западного мира, которые стремились извлечь дополнительный доход из операций с ценными бумагами на развивающихся рынках Бразилии, Китая, России и Индии, тем самым стимулировав распространение и употребление термина БРИК.

Терминологически в различных изданиях и публикациях БРИКС обозначают группой стран, объединением, странами-членами, сообществом, форумом, «пятеркой», а по сути это объединение весьма близких по технологической структуре и уровню развития так называемых индустриализирующихся государств с развивающимся рынком, одни из них относились к странам третьего мира, другие - к странам с трансформирующейся экономикой, которые совместно хотят решать свои и внешние проблемы, не поддаваясь давлению со стороны развитых стран, и прежде всего США. Ныне аббревиатура БРИКС прочно заняла свое место в экономической, статистической, научной и публицистической литературе. Сам термин «аббревиатура» происходит от итальянского «abbreviatura» и латинского «brevis» (краткий), обозначающий сокращение, употребляемое в письме, в разговорной речи. В ряде случаев термин БРИКС еще называют акронимом (от греческого akron - вершина) [2, с. 9, 29].

Западные страны и их представители в международных организациях всячески противодействуют нарастающим и тревожащих их тенденциям в БРИКС. Не случаен факт даже терминологической дискриминации, обозначающей группу из пяти стран, которую называют то «страны БРИКС», «быстро развивающиеся страны», «поднимающиеся страны», «страны третьего мира», то «индустриализирующиеся государства», придающий этому явлению как бы размытый, развивающийся и ма- лозначащий характер, противопоставляющий эти страны экономическим блокам развитых стран. Тем не менее, руководители стран БРИКС намерены расширить сферы своей деятельности, придав группировке «ключевую роль в многополярном мире».

В ряде публикаций страны БРИКС определяются как мир, который возникает на окраинах мировой системы, одной ногой стоящий внутри этой системы, а другой - вне ее (мол, эти страны развиваются внутри западной системы, но критически к ней относятся).

Президент России В. Путин в своем интервью ИТАР-ТАСС назвал страны БРИКС объединением, дал им характеристику и обосновал принципы, на основании которых они были объединены в одну группу: прежде всего, уважение международного права и суверенитета, укрепление центральной роли Организации Объединенных Наций ${ }^{1}$, независимая политика в мировой экономике, взаимодополняющий характер экономик в целях ускорения социально-экономического развития и решения политических проблем стран группы БРИКС 2 .

Заявление В. Путина является не только теоретически, но и практически значимым, поскольку ориентирует данное объединение на принятие конкретных, определенных значимых мер и предложений по выработке единой позиции по специфическим вопросам. В любом случае, современный мир необходимо трансформировать, и БРИКС может стать в этой перестройке действенным инструментом, способным удержать международные отношения и мирохозяйственные связи в устойчивом равновесии, поскольку ситуация в мире, в различных его регионах в целом ухудшается, а кризис охватывает все новые сферы, углубляя межстрановые, культурологические и иные противоречия. Эта ситуация стимулирует появление новых организаций, способных сдержать скатывание в хаос и создать противовес другим силам и блокам (прежде всего англосаксонской модели развития мира), которые извлекают выгоду из регулируемого хаоса.

Задача ныне состоит в том, чтобы опираясь на мощь БРИКС, «создать новую финансовую, политическую и экономическую архитектуру в мире», взамен той, которая была создана в Бреттон-Вудсе (США) в 1944 г. и изживает себя.

\footnotetext{
1 Латтанцио А. Путин хочет усилить стратегическую роль БРИКС [Электронный pecypc]. URL: http://inosmi.ru/ world/. (дата обращения: 05.11.2014).

2 Путин В. Интервью информационному агентству ИТАРTACC 22 марта 2013 года [Электронный ресурс]. URL: http:// news.kremlin.ru/transcripts/17723 (дата обращения: 08.11.2014).
} 


\section{Объект исследования}

Взаимодействие в рамках БРИК началось в сентябре 2006 г., когда по инициативе президента России В. Путина «на полях» сессии Генассамблеи ООН в Нью-Йорке состоялась первая встреча глав внешнеполитических ведомств в этом формате. Ее итогом стало подтверждение участниками заинтересованности в развитии многопланового четырехстороннего сотрудничества, и в июне 2009 г. в г. Екатеринбурге (Россия) прошел первый саммит стран БРИК [3, с. 238]. В декабре 2010 г. к этой весьма разнородной группе стран присоединилась Южно-Африканская Республика, и термин трансформировался в новую аббревиатуру - BRICS. Очередной саммит стран БРИКС состоится 8-9 июля 2015 г. в г. Уфа (Россия), где попытаются выработать механизмы координации стратегических и текущих вопросов стран БРИКС, и прежде всего в финансовой сфере, урегулирования региональных конфликтов, режима нераспространения оружия массового поражения.

Ныне в странах БРИКС проживает 3024 млн чел., или $42 \%$ населения Земли (КНР -1348 млн, Индия - 1275 млн, РФ - 146,2 млн (с учетом Крыма), Бразилия - 202 млн, в 2014 г., ЮАР - 52,9 млн), на них приходится 40,2 \% мирового производства традиционной энергии, 16,1 \% мирового товарооборота, 27 \% мирового ВВП (по ППС в 2013 г., или 16,1 трлн долл., в том числе: КНР - 9,0, РФ и Индия - по 2,1 , ЮАР $-0,402$, Бразилия $-2,5$ трлн долл.), $26 \%$ территории, объем золотовалютных ресурсов на 01.01.2015 г. приблизился к 5,0 трлн долл. (КНР - 4 трлн, РФ - 387 млрд, ЮАР - 45,5 млрд, Индия - 295 млрд, Бразилия - 378 млрд долл.) $\left[4\right.$, с. $71 ; 5$, с. $27 ; 6$, с. 16-17] ${ }^{1}$.

Геополитическому объединению БРИКС уделяется все большее внимание, и это не случайно, поскольку это наиболее динамично развивающиеся страны. Так, темпы роста ВВП, даже в кризисном 2014 г. составили: в КНР - 7,4\% (10,2\% в 2010 г.), РФ - 0,6\% (4,1\% в 2010 г.), Бразилии - 1,0 \% (7,5 \% в 2010 г.), ЮАР $-1,4 \%$ (2,8 \% в 2010 г.), Индия $-4,4$ \% в 2013 г. (10,5 \% в 2010). Хотя БРИКС и не является политико-экономическим союзом, международной организацией или интеграционной группировкой, тем не менее она рассматривается в качестве действенного и растущего субъекта

\footnotetext{
1 Сейфеттин Гюрсель. БРИКС бросает вызов гегемонии США [Электронный ресурc]. URL: http://inosmi.ru/ world/20140805/. (Дата обращения: 06.11.2014); Страны БРИКС: цифры и факты. http://ria.ru/infografika/20150323/ 1053966117.html. (дата обращения:09.05.2015).
}

и инструмента международной политики, экономики, социальной и военной сфер взаимодействия [7, с. 201].

Страны БРИКС, обладая столь мощным военным, экономическим, человеческим, природным, финансовым, индустриальным и научно-техническим потенциалом, способны при умелом и целенаправленном его использовании перекроить всю институциональную и функциональную архитектонику англосаксонской модели современного мира, созданную еще в 1950-е гг. по образу и подобию американской. По всей видимости, страны, образующие ныне БРИКС, продвигаются, хотя и медленно, именно в этом направлении. Попытки расширить группировку, например, за счет Аргентины, пока не принесли желаемых результатов, поскольку страна отягощена финансовыми, территориальными и иными проблемами и в значительной мере привязана к экономическому и культурологическому потенциалу США и ЕС; другой кандидат - Турция, ВВП которой в 2018 г. достигнет 1,3 трлн долл., видит себя новым гегемоном своего региона.

Для стран БРИКС характерны такие особенности развития, как низкий правовой уровень населения и защиты предпринимательства, неразвитость демократических институтов, отсутствие реального разделения исполнительной, законодательной и судебной властей, низкие социальные стандарты и качество жизни, высокий уровень теневого сектора экономики, коррупция, существенный разрыв в доходах различных слоев населения, уровне технологического развития, концентрация власти и имущества у узкой прослойки населения, языковые, демографические, религиозные, пространственные и иные различия. Каждая из них имеет свою долгую и специфическую историю развития, сформировавшиеся уклады жизни, традиции, формы организации труда и производства, экономические, политические, идеологические, социальные и иные диспропорции разного уровня и происхождения. Тем не менее, все это не мешает им продвигаться по пути выработки консолидированных подходов в интересующих их сферах деятельности, шлифуя существующие различия и формируя новую систему взаимоотношений, в том числе в производственной, образовательной, научной, валютно-финансовой, денежно-кредитной и внешнеэкономической сферах, оказывая открытую или негласную поддержку друг другу. Не случаен факт, что ни одна из стран БРИКС не голосовала в ООН за резолюцию, осуждающую Россию за 
присоединение Крыма, а на встрече G-20 в австралийском Брисбене (15.11.2014 г.) лидеры стран БРИКС назвали антироссийские санкции незаконными.

Россия - наиболее активный участник этой группы стран по всему спектру взаимоотношений. Так, в 2013 г. Президент России утвердил «Концепцию участия Российской Федерации в объединении БРИКС». В данном документе определены подходы России к сотрудничеству с Бразилией, Индией, Китаем и Южной Африкой в таких сферах, как международное политическое, торгово-экономическое, промышленное, валютно-финансовое, энергетическое сотрудничество, наука, техника, инновации, здравоохранение, сельское хозяйство, культура, спорт, туризм, образование, молодежный обмен ${ }^{1}$.

Если изначально объединение поставило перед собой в качестве основой задачу развития экономического сотрудничества, то в последующие годы эта цель трансформировалась от диалогового форума и инструмента координации по ограниченному кругу проблем до полноформатный механизм текущего и стратегического взаимодействия по ключевым вопросам мировой политики и экономики. Впоследствии страны БРИКС продолжили процесс институционализации, сформировав Деловой совет БРИКС и Бизнес-форум БРИКС, на которых в предверии ежегодных саммитов проходят встречи представителей бизнеса и руководства стран БРИКС по интересующим их темам и проблемам. С этой же целью создана Парламентская ассамблея стран БРИКС (международной организации сотрудничества), которая позволит перевести встречи этих стран в область регулируемого взаимодействия на международной арене.

В условиях нарастания кризисных явлений в мировой экономике, особенно после 2008 г., под давлением западных стран, страны БРИКС подошли к осознанию необходимости принятия конкретных решений по переустройству своей и мирохозяйственной структуры. Так, в Форталезе, на 5-м саммите БРИКС (15 июля 2014 г., Бразилия) были приняты два важных решения, бросающих вызов мировому экономическому порядку, созданному Западом после Второй мировой войны. Лидеры БРИКС подписали соглашение о создании виртуального пула резервных валют на основе между-

\footnotetext{
${ }^{1}$ Концепция участия Российской Федерации в объединении БРИКС. Утверждена Президентом РФ 21 марта 2013 года [Электронный ресурc]. URL: http ://www. news. kremlin. $\mathrm{ru} / \mathrm{news} / 17715$ (Дата обращения: 08.11. 2014).
}

народных резервов, находящихся под управлением государственных или национальных банков на условиях срочности, платности и возвратности (Contingent Reserve Arrangement) - альтернативы Международного валютного фонда (МВФ). Первоначальный размер пула валютных резервов составит 100 млрд долл. В случае если на национальные валюты стран-участниц будет совершена спекулятивная атака, они смогут использовать валюту из резерва. Доля Китая как страны, обладающей крупнейшим мировым экономическим и финансовым потенциалом, а также значительными золотовалютными резервами, составит 41 млрд долл., Бразилия, Индия и Россия вкладывают по 18 млрд, ЮАР - 5 млрд долл.

Наряду с резервным фондом, который станет альтернативой МВФ, БРИКС учредил инвестиционный банк - аналог Всемирного банка (WB). Уставной капитал Нового банка развития (New Development Bank) составит 50 млрд долл. (по 10 млрд долл. от страны), а штабквартира будет находиться в г. Шанхай (КНР). 9 марта 2015 г. Россия ратифицировала соглашение о Новом банке развития БРИКС. При необходимости уставной капитал банка может быть увеличен до 100 млрд долл. В отличие от резервного фонда, вложить деньги в этот банк и стать его партнером может любая развивающаяся страна. Банк нацелен на финансирование долгосрочных инвестиционных проектов развивающихся экономик, прежде всего инфраструктурных, а также возобновляемых источников энергии.

Эти два института в ближайшем будущем могут стать конкурентами МВФ и Всемирному банку, поскольку будут повышаться экономический вес и ресурсы БРИКС, а в последующем им удастся стать альтернативой МВФ и ВБ, контролируемым ныне США. Следует отметить, что БРИКС настаивает на идее реформирования МВФ, которая бы отражала реальную расстановку сил, сложивнуюся ныне в мире. Форталезская декларация практически в ультимативной форме предупреждает Запад (и прежде всего, не расположенные к реформам МВФ и американский Конгресс) о необходимости провести реформы в 2015 г. и достичь окончательной договоренности по новой формуле расчета квот с нынешних 2,5 \% - для РФ, 2,44 \% - для Индии, 4 \% - для Китая, против 17,69 \% - для США. Страны БРИКС отметили, что промедление с созданием более равноправной структуры этого фонда «негативно сказывается на его легитимности, репутации и эффективности». 
Внешняя торговля РФ и регионов Урала, млн долл.

\begin{tabular}{|c|c|c|c|c|c|c|c|c|c|c|}
\hline \multirow[b]{2}{*}{ Показатели } & \multirow[b]{2}{*}{ Год } & \multirow[b]{2}{*}{ РФ } & \multicolumn{2}{|c|}{ Республики } & \multicolumn{6}{|c|}{ Области } \\
\hline & & & 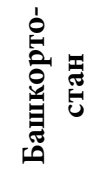 & 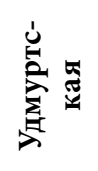 & 氧 & 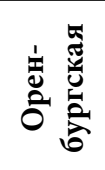 & 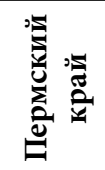 & 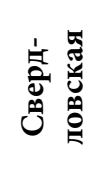 & 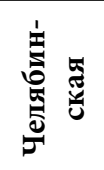 & 总 \\
\hline Экспорт & \multirow{2}{*}{2010} & 396644 & 9359 & 230,4 & 221,1 & 2990 & 4310 & 9037 & 5138 & 45267 \\
\hline Импорт & & 229045 & 621,9 & 248,5 & 173,3 & 1114,6 & 633,5 & 3419 & 2908 & 2156 \\
\hline Экспорт & \multirow{2}{*}{2011} & 526481 & 10723 & 1124,1 & 328,0 & 2368,7 & 6998,3 & 8895,3 & 5499,0 & 60042,8 \\
\hline Импорт & & 305605 & 939,7 & 448,7 & 151,8 & 906,3 & 823,6 & 3851,5 & 2445,4 & 3951,1 \\
\hline Экспорт & \multirow{2}{*}{2012} & 525334 & 13109 & 2148 & 384 & 3723 & 8641 & 10729 & 5857 & 61889 \\
\hline Импорт & & 314150 & 1380 & 401 & 179,8 & 1138 & 950 & 4013 & 3821 & 2423 \\
\hline Экспорт & \multirow{2}{*}{2013} & 527266 & 14621 & 1259,7 & 468,3 & 3509 & 7401,4 & 8724,3 & 5363,9 & 49383 \\
\hline Импорт & & 314967 & 1168,2 & 741,5 & 149,3 & 858,2 & 1155,6 & 4170,5 & 4000,9 & 2064,7 \\
\hline Экспорт & \multirow{2}{*}{2014} & 496700 & 12770 & 1222,2 & 258,5 & 2220,6 & 7643,2 & 7672,9 & 4162,4 & 22510,5 \\
\hline Импорт & & 308000 & 1003,9 & 648,6 & 127,2 & 610,4 & 1071,2 & 3063,1 & 1643,2 & 2013,0 \\
\hline \multirow{3}{*}{$\begin{array}{l}\text { Предпр. осу- } \\
\text { ществ. ВЭД, ед. }\end{array}$} & 2012 & - & 19 & 6 & 5 & 12 & 22 & 52 & 31 & 12 \\
\hline & 2013 & - & 13 & 3 & 2 & 8 & 23 & 28 & 17 & 7 \\
\hline & 2014 & - & 14 & 3 & 2 & 9 & 22 & 29 & 13 & 7 \\
\hline
\end{tabular}

* по данным [8, с. 197], а также Министерства международных и внешнеэкономических связей Свердловской области [Электронный pecypc]. URL: http: //mvs.midural.ru/news/; Федеральной таможенной службы. Уральское таможенное управление. [Электронный ресурс]. URL: http://utu.customs.ru; Приволжского таможенного управления [Электронный pecypc]. URL: http://ptu.customs.ru. (дата обращения:06.03.2015); журнала Эксперт-Урал. 2015. № 18-19 (644). 27 апреля 10 мая. С. 56-60.

** предприятия, осуществляющие ВЭД с объемами экспорта свыше 3 млн долл. в год.

Растет торговый оборот стран БРИКС, достигнув в 2014 г. 6,14 трлн долл., или $17 \%$ от мирового объема торговли. Переход стран БРИКС во взаимной торговле на национальные валюты позволит нарастить объемы торговли и снизить операционные издержки.

В этих условиях внешнеэкономическая деятельность стран БРИКС становится одной из действенных форм стимулирования развития регионов мира. Так, внешнеторговый оборот в мире вырос с 2,2 \% в 2012 г. до 4,7 \% в 2014 г., в России - достигнув своего максимума в 2008 г. 763,5 млрд долл., снизился, вернувшись на докризисный уровень лишь в 2011 г., (832,0 млрд долл.) и медленно рос в последующие годы, достигнув 842,2 млрд долл. в 2013 г., а в 2014 г. вновь снизился до 804,7 млрд долл. (табл. 1).

В целях налаживания межрегионального взаимодействия, привлечения иностранных инвестиций, диверсификации внешнеэкономических связей и расширения промышленной кооперации глава МИД России С. Лавров на заседании совета глав субъектов при МИД РФ 28.11.2014 г. предложил создать совет сотрудничества регионов стран, входящих в БРИКС.

Заметный вклад в эту деятельность вносят регионы Урала. Международной специализации Уральский регион обязан продукции металлургического комплекса, на которую при- ходится 50 \% всей металлургии России, а доля продукции металлургии в экспорте России составила 13,0 \% в 2010 г., при росте самого экспорта до 51,3 млрд долл. В УЭР ее удельный вес превышает 40 \%, что почти втрое выше среднероссийского показателя.

Анализ предприятий региона показывает, что в мирохозяйственные связи включен весьма узкий сектор базовых отраслей уральской экономики. Так, из 4369 юридических лиц УрФО, участвовавших в 2014 г., во внешнеэкономической деятельности, на Средний Урал приходилось 2370 участников (снижение на 5,1\%, стран экспортеров - на 4,2 \% и импортеров - на 0,8 \%), на Южный Урал - 1350, на Зауралье - 124, на Тюменскую область 306 , на ХМАО - 175, ЯНАО - 64 участника. Из них осуществляли ВЭД с объемами экспорта свыше 3 млн долл. в год на Среднем Урале лишь 29 участников в 2014 г., 28 - в 2013 г., 52 - в 2012 г., на Южном Урале - 13, 17 и 31, в Зауралье -2 , 2 и 5, в Тюменской области -7 , 7 и 13, в Оренбургской - 9, 12 и 8, в Пермском крае - 22, 22 и 23, в Удмуртской Республике 3, 3 и 6, Республике Башкортостан - 14, 13 и 19 участников соответственно ${ }^{1}$.

${ }^{1}$ Эксперт-Урал. 2015. № 18-19 (644). 27 апреля - 10 мая. C. 56-60. 
Товарная структура экспорта и импорта регионов Урала, 2014 г., млн долл.

\begin{tabular}{|c|c|c|c|c|c|c|c|c|c|c|c|c|}
\hline \multirow{3}{*}{$\begin{array}{l}\text { Регион/ } \\
\text { область }\end{array}$} & \multicolumn{12}{|c|}{ Показатель } \\
\hline & \multicolumn{2}{|c|}{$\begin{array}{c}\text { Продовольст- } \\
\text { венные то- } \\
\text { вары и сель- } \\
\text { хозсырье } \\
\text { (гр. 1-24) } \\
\end{array}$} & \multicolumn{2}{|c|}{$\begin{array}{c}\text { Продукция } \\
\text { топливно- } \\
\text { энергетиче- } \\
\text { ского ком- } \\
\text { плекса (гр. 27) }\end{array}$} & \multicolumn{2}{|c|}{$\begin{array}{c}\text { Продукция } \\
\text { химической } \\
\text { промышлен- } \\
\text { ности, каучук } \\
\text { (гр. 28-40) } \\
\end{array}$} & \multicolumn{2}{|c|}{$\begin{array}{c}\text { Древесина и } \\
\text { целлюлозно- } \\
\text { бумажные из- } \\
\text { делия } \\
\text { (гр. 44-49) }\end{array}$} & \multicolumn{2}{|c|}{$\begin{array}{c}\text { Металлы и } \\
\text { изделия из } \\
\text { них } \\
\text { (гр. 72-83) }\end{array}$} & \multicolumn{2}{|c|}{$\begin{array}{c}\text { Машины, } \\
\text { оборудование } \\
\text { и транспорт. } \\
\text { средства } \\
\text { (гр. 84-90) } \\
\end{array}$} \\
\hline & $\begin{array}{c}\text { экс- } \\
\text { порт }\end{array}$ & $\begin{array}{c}\text { им- } \\
\text { порт }\end{array}$ & $\begin{array}{l}\text { эКс- } \\
\text { порт }\end{array}$ & $\begin{array}{c}\text { им- } \\
\text { порт }\end{array}$ & $\begin{array}{c}\text { экс- } \\
\text { порт }\end{array}$ & $\begin{array}{c}\text { им- } \\
\text { порт }\end{array}$ & $\begin{array}{c}\text { экс- } \\
\text { порт }\end{array}$ & $\begin{array}{c}\text { им- } \\
\text { порт }\end{array}$ & $\begin{array}{c}\text { эКс- } \\
\text { порт }\end{array}$ & $\begin{array}{c}\text { им- } \\
\text { порт }\end{array}$ & $\begin{array}{c}\text { экс- } \\
\text { порт }\end{array}$ & $\begin{array}{c}\text { им- } \\
\text { порт }\end{array}$ \\
\hline Башкирия & 15,7 & 22,1 & 11063 & 6,6 & 643 & 234 & 64,2 & 3,9 & 230 & 85,7 & 735 & 627 \\
\hline Удмуртия & 1,45 & 3,6 & 1099 & 0,4 & 23,3 & 307 & 4,5 & 8,2 & 19,7 & 44,6 & 33,6 & 270 \\
\hline Пермский край & 16,5 & 11,8 & 3119 & 61,6 & 3757 & 177 & 409 & 40,5 & 155 & 4,3 & 135 & 691 \\
\hline Оренбургская & 18,9 & 14,4 & 1240 & 6,8 & 81,6 & 31,7 & 0,156 & 1,35 & 812 & 32,7 & 66,9 & 510,8 \\
\hline Свердловская & 61,5 & 183 & 245,3 & 48,6 & 1373 & 425 & 214,9 & 48,6 & 4308 & 419 & 1143 & 1690 \\
\hline Челябинская & 62,4 & 60,6 & 70,7 & 90,3 & 70,7 & 190 & 0,0 & 14,8 & 3573 & 254,7 & 274 & 951,1 \\
\hline Курганская & 3,5 & 1,5 & 0,0 & 73,7 & 12,9 & 0,0 & 3,3 & 2,54 & 23,7 & 11,4 & 215 & 41,4 \\
\hline Тюменская & 10,0 & 16,5 & 1820 & 28,5 & 682 & 31,9 & 22,7 & 6,8 & 7,5 & 39,9 & 27,7 & 414,8 \\
\hline $\mathrm{XMAO}$ & 0,0 & 9,9 & 19251 & 4,96 & 0,0 & 28,5 & 58,4 & 1,24 & 0,0 & 120,5 & 155 & 1070 \\
\hline ЯНАО & 4,0 & 0,0 & 484 & 0,6 & 0,5 & 0,8 & 0,0 & 0,4 & 0,0 & 63,5 & 18,7 & 125,6 \\
\hline
\end{tabular}

* Министертство международных и внешнеэкономических связей Свердловской области. [Электронный pecypc]. URL: http: //mvs.midural.ru/news/; Федеральная таможенная служба. Уральское таможенное управление. [Электронный ресурс]. URL: http://utu. customs.ru; Приволжское таможенное управление. [Электронный ресурc]. URL: http://ptu.customs.ru. (дата обращения:06.03.2015).

В структуре промышленного производства УЭР на рубеже веков на долю топливно-энергетического комплекса приходилось $28,0 \%$, черной металлургии $-17,6 \%$, машиностроения и металлообработки - 15,8 \%, легкой и пищевой промышленности - около 8 \%.

Несмотря на снижение темпов роста ВВП (до 0,6 \% в 2014 г.) и промышленного производства в стране (до 0,4 \% в 2013 г., а в Уральском регионе - до 1,1 \% в 2013 г.), [9, с. 15-20] внешнеэкономическая деятельность продолжает наращивать свои обороты. Крупными экспортерам России и регионов Большого Урала даже в период рецессии продолжают оставаться ХМАО (Тюменская область) - 19475,2 млн долл. в 2014 г., Свердловская область - 7672,9 млн, Республика Башкортостан - 12770,8 млн, Пермский край -7643 млн долл.

Товарная структура экспорта и импорта регионов зоны Большого Урала не претерпела существенных изменений за 2014 г. (табл. 2). Это касается экспорта металлопродукции (ММК 1564 млн долл. в 2013 г., НТМК, УГМК - 1281 млн долл. в 2013 г., Мечел, ТМК), нефтегазовых ресурсов Тюменской области, ХМАО и ЯНАО, химикалиев («Уралкалий», Пермский край, 2109 млн долл. в 2013 г.), драгоценных и редкоземельных металлов (Екатеринбургский ОЦМ, 141 млн долл. в 2013 г.), титановой продукции («ВСМПО-Ависма»), ядерных и космических технологий, вагоно- и танкострое- ние («Уралвагонзавод», г. Екатеринбург), авиастроительной продукции («НПО «Искра», «Протон-ПМ» - Пермский край), радиоактивных элементов («Уральский электрохимический комбинат» в Свердловсой области, «Маяк» - в Челябинской области), авиамоторы (Пермский край); производители вооружений (Свердловская область - ГУП ПО «Уралвагонзавод», Машиностроительный завод им. М. И. Калинина, ОАО «Уралмашзавод»36,7 млн долл. в 2013 г., ОАО «Уралтрансмаш»; Пермский край - АО «Велта», ОАО «Мотовилихинские заводы»; Удмуртская Республика - АО «Ижмаш», Ижевский электромеханический завод, ГП «Воткинский машзавод», концерн «Калашников») и т. д.

Заметный вклад вносит Урал в российский экспорт по таким товарным группам, как руды, концентраты, металлы и изделия из них; машины, оборудование и транспортные средства; топливо, сырье, электроэнергия; химические продукты и строительные материалы; лесоматериалы и целлюлозно-бумажные изделия.

За пределы Урала в конце 1980-х гг. вывозилось почти 44 \% продукции металлургии; 37 \% химической и нефтехимической продукции; 36 \% машиностроения; 34 \% продукции лесной, целлюлозной и деревообрабатывающей промышленности. В то же время в регион завозились 3/4 всего потребляемого твердого топлива, 90 \% газового, 60 \% железной руды (из 
Монголии, Украины и Казахстана), подавляющая часть потребительских товаров и продуктов питания [10, с. 58$]$.

За годы перестройки Урал потерял многие свои экспортные позиции, и лишь наличие разнообразных топливно-сырьевых ресурсов, мощного производственного парка, крупного научного потенциала, высококвалифицированных кадров позволило региону удержаться в водовороте перестроечных процессов, поддержать угасающий экспорт машиностроения и нарастить экспорт энергоносителей, все больше специализируясь на экспорте продукции топливно-сырьевого комплекса.

Среди проблем, затрудняющих экспорт из УЭР, можно выделить следующие: монокультурность структуры производства (топливносырьевая, металлургическая, лесоперерабатывающая); слабое участие в международном разделении труда; изолированность машиностроительного комплекса от внешних рынков; слабые экспортные стимулы для производителя; вялая реакция производителя на изменение конъюнктуры рынка; слабость конверсионных производств во внешнеэкономической деятельности; неотработанность системы международного маркетинга и менеджмента.

Ведущей статьей экспорта УЭР является товарная группа «руды и концентраты, металлы и изделия из них», на которую приходилось до 35 \% суммарного уральского экспорта. Это, прежде всего, продукция черной металлургии - 17,1 \% уральского экспорта, цветной металлургии - 10,1 \%, калийные соли - 9,0 \%, асбест, хромиты - около $2 \%$.

Средний и Южный Урал - основные производители и экспортеры продукции черной и цветной металлургии в России. Особенность Урала проявляется в том, что больше половины производимой металлопродукции потребляется внутри региона. Это, прежде всего, продукция таких металлоемких производств, как черная и цветная металлургия, транспортное машиностроение, автомобильная промышленность, дорожное и энергетическое машиностроение, нефтехимическая промышленность.

В целом на рубеже веков на предприятиях Урала производилось 56 \% глинозема РФ, 36 \% рафинированной меди, добывалось 97 \% бокситов, осуществлялась переработка $100 \%$ титана и магниевых сплавов, 64 \% цинка, $15 \%$ свинца и $8 \%$ алюминия. Цветная металлургия Урала значительно меньше ориентирована на экспорт своей продукции, а в большей мере - на внутреннее потребление. Так, доля Богословского и Уральского алюминиевых за- водов в экспорте первичного алюминия составила всего 7 \%, а во внутреннем потреблении 25 \%; доля Кыштымского медеэлектролитного завода и «Уралэлектромеди» в экспорте рафинированной меди - 17,8 \%, а во внутреннем потреблении РФ - 69 \%.

Наиболее крупная и доходная статья экспорта Уральского региона - нефтегазовое сырье. Его товарное наполнение образуют нефть Тюменской, Оренбургской областей и Пермского края, республик Башкортостан и Удмуртской; природный газ ХМАО и ЯНАО, Оренбуржья. Из добытых в стране в 2010 г. 505 млн т нефти было экспортировано 247 млн т, из них 220,7 млн т в страны дальнего зарубежья и 7,8 млн т в страны ближнего зарубежья, что на 23 \% ниже уровня 2009 г. Доход от экспорта нефти из РФ составил 134,7 млрд долл., от экспорта 133 млн т нефтепродуктов - 70 млрд долл. Некоторое сокращение экспорта нефти в страны ближнего зарубежья связано со снижением на 8,6 млн т (или на 40 \% к 2009 г.) поставок на нефтеперерабатывающие заводы Белоруссии. Экспорт газа в страны Европы в 2013 г. составил 138 млрд $\mathrm{M}^{3}$ и еще 58 млрд $3 \mathrm{~m}^{3}$ - в страны СНГ. Основной экспортер этого газа - ХМАО и ЯНАО, а также Башкортостан. Так, объем экспорта в стоимостном выражении в 2013 г. составил у: Сургутнефтегаз - 21984 млн долл., «Башнефть» -6888 млн долл., Новатэк 2518 млн долл. ${ }^{1}$

Специфика уральских предприятий проявляется в том, что, имея мощную горно-металлургическую базу, регион оказался вне сырьевой базы и ныне вынужден завозить большую часть сырья из стран ближнего, а порой и дальнего зарубежья. На долю предприятий Урала приходилось $10,8 \%$ российского экспорта чугуна, 45,4 \% проката черных металлов, $12,8 \%$ ферросплавов, $42,9 \%$ стальных труб. Основными экспортерами по товарной группе «черные и цветные металлы» являлись: Магнитогорский металлургический комбинат (1564 млн долл. в 2013 г., 2615,5 млн долл. в 2011 г., 1002 млн долл. в 2000 г.), Челябинский электрометаллургический комбинат $(411,0$ млн долл. в 2011 г.), Нижнетагильский металлургический комбинат (305 млн долл.в 2011 г.), Уральская горно-металлургическая компания (1281 млн долл. в 2013 г., 1919,8 млн долл.в 2011 г. и 354 млн долл. в 2000 г.), корпорация «ВСМПО-Ависма» (677 млн долл. в 2013 г., 418,4 млн долл. в 2011 г. против 122 млн долл.в

${ }^{1}$ Рейтинг крупнейших экспортеров // Эксперт-Урал. 2014. № 18-19 (599) (28 апр. - 11 мая). С. 66-70. 
2000 г.), Группа «Русская медная компания» (1298,7 млн долл. в 2013 г. и 1710,6 млн долл. в 2011 г.), Уральская сталь - 856,9 млн долл в 2011 г., Нижнетагильский металлургический комбинат - 995,4 млн долл. в 2011 г., ВИЗСталь - 261,4 млн долл. в 2011 г. и 198,8 млн долл. в 2013 г. ${ }^{1}$

Крупной статьей экспорта региона являются товары по группе «химия и нефтехимия» (их доля в экспорте региона составляет 5 \%), которая в основном представлена экспортом удобрений - это Уралкалий и Сильвинит (объединились в декабре 2010 г. в одну - Уралкалий, их экспорт в 2013 г. составил 2109,9 млн долл. В 2013 г. «Уралкалий» пытался обанкротить «Беларускалий» и поглотить ее, но неудачно), на нее приходится 81 \% внешних поставок зоны «Большого Урала» по данной группе товаров. Основные производители товаров по группе «химия и нефтехимия» сосредоточены в Республике Башкортостан, которую называют самым «химизированным» регионом РФ. Объем экспорта Стерлитамакского нефтехимзавода достиг 207 млн долл. в 2013 г., Башкирской содовой компании - 11,0 млн долл. Причем здесь сохраняется устойчивая тенденция в структуре производства и экспорта продукции: 15-20 \% - это изделия химической промышленности (кальцинированная сода) и 80-85 \% - нефтехимической (синтетический каучук, орто- и параксилолы, спирты).

Падающей статьей экспорта Урала является товарная группа «машины, оборудование и транспортные средства» (с 15,6 \% в 1986 г. до 7 \% в 1996 г.). Урал до 1990 г. был монополистом в производстве и экспорте из РФ электровозов и тепловозов (42,6 \%), грузовых автомобилей (11\%), кузнечно-прессового оборудования (33,3 \%), подшипников, мотоциклов (94 \%), металлорежущих станков (27,1 \%).

Основными производителями данной продукции ныне являются ОАО «Уралвагонзавод» (в страны СНГ было реализовано в 2010 г. 90,6 тыс. вагонов, что на 58 \% выше уровня 2009 г., в целом за период 2009-2013 гг. УВ3 произвел и реализовал свыше 103 тыс. вагонов на сумму 189,7 млрд руб., в том числе в 2010 г. 20 тыс., в 2011 г. - 25 тыс. вагонов и цистерн, в 2012 г. - 28 тыс. вагонов, сам экспорт в денежном выражении в 2013 г. составил 5,9 млн долл.), «Уфимское моторостроительное производственное объединение», «Уралвагонзавод» (танки Т-72 и Т-90), «Курганмашзавод» (боевые машины пехоты), «Мотовилихинские заводы»

\footnotetext{
${ }^{1}$ Там же. С. 66-70.
}

(реактивные системы залпового огня «Смерч»), ПО «Уральский оптико-механический завод» (комплексы и комплектующие для авиационной и морской техники).

Восстанавливают объемы производства и экспорта горношахтного, металлургического, нефтегазового оборудования «Уралмаш», «Уралхиммаш», «Уралэлектротяжмаш» и другие машиностроительные предприятия региона.

Небывало ухудшилась ситуация (в связи с приватизацией и дезорганизацией производства и экспорта) на лесозаготовительных и лесоперерабатывающих предприятиях УЭР. Доля экспорта по товарной группе «лесоматериалы и целлюлозно-бумажные изделия» снизилась с 10 \% в 1986 г. до 2,23 \% в 1996 г. и до 2,2 \% в 2010 г.

\section{Управление внешнеэкономической деятельностью региона}

Некогда закрытые для иностранцев и инвесторов регионы Урала (в том числе и Свердловской области) в начале 1991 г. сняли ограничения на международные отношения и внешнеэкономические связи. Область одной из первых в РФ создала в составе исполнительных органов внешнеэкономические службы.

В 1990 г. Советом Министров СССР была выдана Свердловской области генеральная лицензия на осуществление экспортно-импортных операций в пределах региональной квоты, которая на 1991 г. составила 1300 млн инв. руб. (867 млн долл. США). В соответствии с генеральной лицензией Свердловский облисполком получил право выдавать разрешения на получение лицензий на экспорт стратегических товаров.

Решением от 16 июля 1991 г. № 365 в структуре облисполкома было образовано управление, занимающееся вопросами развития международного сотрудничества.

Нормативно-правовая база развития международного сотрудничества Свердловской области определяется Конституцией РФ, законами РФ, постановлениями и решениями Правительства РФ, отраслевых министерств и ведомств, Уставом и законами области, нормативными актами, подписанными с федеральным центром губернатором и Правительством Свердловской области, законодательными актами органов власти на местах.

Подписанный в январе 1996 г. Договор о разграничении предметов ведения и полномочий между органами государственной власти РФ и органами государственной власти Свердловской области являются основой раз- 
вития международных и внешнеэкономических связей региона.

На основе Договора о разграничении предметов ведения и полномочий к совместному ведению России и Свердловской области отнесены: получение иностранных кредитов под гарантии бюджетных доходов Свердловской области; координация деятельности по созданию и функционированию свободных экономических зон; разработка и проведение политики привлечения иностранных инвестиций.

Правительство области обладает правом создания страховых и залоговых фондов (в том числе из драгоценных металлов и драгоценных камней на возвратной основе) в сфере внешнеэкономической деятельности для привлечения иностранных займов и получения иностранных кредитов, правом заключения соглашений с субъектами иностранных федеративных государств, административно-территориальными образованиями иностранных государств, министерствами и ведомствами иностранных государств.

Первые годы работы Управления ММиВЭС позволили приобрести опыт планирования и управления внешнеэкономическими процессами в регионе, освоить азы сотрудничества региона с иностранными партнерами. В то же время стало очевидно, что внешнеэкономическая деятельность, являясь важным фактором модернизации, структурной перестройки и создания конкурентоспособной региональной экономики, требует осознанной долгосрочной стратегии и разработки планов развития региона.

Департамент ММиВЭС Свердловской области в ноябре 1998 г. получил статус министерства. Им в рамках концепции ВЭД в 1997 г. была разработана и утверждена «Программа развития экспортного комплекса Свердловской области».

В 1998 г. ММиВЭС Свердловской области разработало и запустило в интернет организационно-информационную систему «Экспортная карта Свердловской области» (ЭКСО), в которой содержится объемная база данных о регионе, предприятиях области и предлагаемой ими на экспорт продукции. Благодаря этой системе около 3000 предприятий области получили доступ к экспонированию информации о своей продукции во все регионы мира. Такая система также стала одной из первых в регионах России.

Важной мерой развития международных и внешнеэкономических связей региона является формирование инфраструктуры внешне- экономических связей приема иностранцев. Этому ныне служат создаваемая таможенная и транспортная инфраструктура, сеть отелей, выставок, система транспортного сообщения, аэропортов, офисов, залов для проведения встреч и мероприятий на международном уровне.

Важное место в развитии инфраструктуры внешнеэкономических связей предприятий области занимают открытые в Свердловской области иностранные дипломатические, торговые и культурные представительства. На 01.01.2014 г. в области насчитывалось 23 дипломатических и консульских представительств, область осуществляла внешнеэкономические связи со 152 государствами мира, против 133 в 2008 г., в регионе находятся представительства более чем 400 иностранных фирм.

Возрастающая роль в системе органов инфраструктуры поддержки внешнеэкономической деятельности области отводится центрам подготовки и переподготовки кадров, необходимых для обеспечения нужд служб ВЭД области. Этим занимаются 7 высших учебных заведений Екатеринбурга. Кроме них в сфере внешнеэкономической деятельности и подготовки кадров участвуют Американский центр предпринимательства, Институт маркетинга и экономического мониторинга, Институт международных связей, Уральское таможенное управление ГТК, Уполномоченный МВЭС по Уральскому региону, Уральская торгово-промышленная палата, Уральский региональный центр Федеральной службы России по валютному и экспортному контролю.

Для обеспечения постоянного взаимодействия органов управления Свердловской области с производителями и экспортерами при Свердловском областном Союзе промышленников и предпринимателей создана Межведомственная комиссия по проблемам развития внешнеэкономического комплекса Свердловской области. Проблемами информационного обеспечения занимается Региональный центр аналитического и информационно-консультационного обеспечения ВЭД Свердловской области.

В целях координации деятельности многочисленных служб и ведомств при Правительстве Свердловской области создан Координационный совет по кадровому обеспечению внешнеэкономической деятельности области. Состав Совета формируется из руководителей правительства области, администраций округов, руководителей крупных городов и их внешнеэкономических служб, ведущих 
ученых, представителей вузов и образовательных учреждений различных организационноправовых форм, руководителей предприятийэкспортеров, работников средств массовой информации.

Основой многоуровневой системы образования стал Межотраслевой региональный центр повышения квалификации и переподготовки специалистов Свердловской области, функции которого возложены на Институт переподготовки кадров УрФУ. Центр на основе государственно-частного партнерства объединяет усилия образовательных учреждений различных организационно-правовых форм в подготовке кадров. Одним из направлений осуществления кадровой политики стала реализация Президентской программы подготовки управленческих кадров для организаций народного хозяйства РФ.

В Свердловской области создано региональное отделение Федеральной комиссии по организации подготовки управленческих кадров. В соответствии с постановлением Правительства Российской Федерации от 24.03.2007 г. № 177 «О подготовке управленческих кадров для организаций народного хозяйства Российской Федерации в 2007/08 - 2014/15 учебных годах» ежегодно проводится отбор кандидатов на подготовку в рамках Государственного плана подготовки управленческих кадров для организаций народного хозяйства Российской Федерации. Свердловская область участвует в реализации Государственного плана с 1998 г. За 15 лет профессиональную переподготовку прошли 1990 руководителей, 626 специалистов стажировались за рубежом. Эта программа бизнесобразования реализуется на основе государственно-частного партнерства и предназначена для руководителей высшего звена российских предприятий и организаций (проектно-ориентированные образовательные программы, тип «А»-advanced) продолжительностью 550 часов) и среднего звена (базовые образовательные программы, тип «В»- basic) продолжительностью 550 часов). При этом в конкурсном отборе учитываются такие критерии, как возраст до 40 лет (старше 40 - по ходатайству предприятия), образование - высшее профессиональное; общий стаж работы не менее 5 лет, опыт работы на управленческих должностях не менее 3 лет, владение иностранным языком, планируемое участие в реализации проекта развития предприятия (организации) или его подразделения.

На 1-м этапе подготовки специалистов в Свердловской области участвуют: 1) Бизнесшкола Уральского федерального универси- тета (программы: стратегия управления предприятием); топ-менеджер: развитие стратегического мышления; менеджер проектов: технологии проектного управления; 2) Институт бизнес-образования УрГЭУ (финансовый менеджмент); 3) Институт корпоративного управления и предпринимательства УрГЭУ (корпоративнвый менеджмент).

Финансирование подготовки специалистов в вузах осуществляется за счет средств федерального и областного бюджетов в размере $66 \%$ от общей стоимости обучения, а также за счет средств рекомендующего предприятия - $34 \%$. Базовая стоимость обучения специалистов в образовательных учреждениях Свердловской области по программе типа «А» составляет 100 тыс. руб., по программе типа «В» -60 тыс. руб. Проведение конкурсного отбора финансируется за счет собственных средств специалиста и составляет на программу типа «В» - около 3,1 тыс. руб., на программу типа «А» $-4,4$ тыс. руб. Участие в стажировке полностью обеспечивается за счет федерального бюджета и принимающих зарубежных компаний. ${ }^{1}$

Материально-техническое и информационное обеспечение мероприятий, реализуемых в рамках выполнения Государственного плана подготовки управленческих кадров для организаций народного хозяйства Российской Федерации, осуществляется Министерством международных и внешнеэкономических связей Свердловской области.

В целях повышения эффективности инвестиционной политики, создания условий, способствующих росту инвестиционной активности, разрабатываются новые механизмы, инструментарий и технологии иностранного инвестирования. С этой целью при губернаторе области создан Консультативный совет по иностранным инвестициям. Создана специализированная организация - Фонд поддержки инвестиций при губернаторе Свердловской области, координирующая усилия исполнительной власти, банковских и предпринимательских структур по привлечению и использованию иностранных инвестиций.

Координацию работы органов, предприятий и организаций в сфере внешнеэкономической деятельности в регионе осуществляет Министерство международных и внешнеэкономических связей, которое включает в себя три управления: международных связей, внеш-

\footnotetext{
Государственная программа подготовки кадров. [Электронный ресурc]. URL: http://mvs.midural.ru/ gosudarstvennyi-plan-podgotovki-upravlencheskikh-k (дата обращения: 01.11.2014).
} 
неэкономической деятельности и инвестиций, организационное, а также отдел международного протокола. Аналогичные подразделения созданы и в других субъектах Уральского региона, занимающихся внешнеэкономической деятельностью [11, с. 32-44].

\section{Внешнеэкономические партнеры и конкуренты Среднего Урала}

Совокупность мер по стимулированию развития ВЭД позволила увеличить внешнеторговый оборот области, достигнувший своего максимума в 2010 г. 11683,8 млн долл., но в последующие годы снизился, составив 10028,0 млн долл. в 2013 г., и вырос до 10736 млн долл. в 2014 г. В 2013 г. произошло сокращение внешнеэкономической деятельности области с развитыми странами на 7,0 \% и его рост со странами СНГ - на $12 \%$.

Основные партнеры предприятий Среднего Урала во внешнеэкономических связях все те же. Правда, в последние годы, особенно в период принятия экономических санкций, их активность в регионе заметно снизилась. Тем не менее, внешнеторговый оборот довольно устойчив: экспорт с США в 2013 г. - 1499,2 млрд долл., или 20,8 \% всего экспорта, импорт 255,4 млрд долл. (9,1 \%); с Германией: экспорт - 604,2 млн долл., или 8,4 \%, импорт - 394,6, или 14,1\%; с Нидерландами: экспорт - 804,9 млн долл., или $11,1 \%$. Заметная тенденция в импорте области - это трехкратное сокращение внешнеэкономических связей с Украиной - с 343,6 млн в 2012 г. до 163,7 млн в 2013 г. и 119,6 млн долл. в 2014 г.

Средний Урал все более укрепляет свои внешнеэкономические связи со странами БРИКС (табл. 3).

Китай становится основным внешнеэкономическим партнером не только России $(95,28$ млрд долл в 2014 г. против 88,8 млрд в 2013 г.), оттеснив Нидерланды на вторые позиции (76 млрд долл.), а Германию на третьи (75 млрд долл.), но и Среднего Урала - его доля в импорте области в 2014 г. составила 20,3 \%, или 620,3 млн долл.

Тесное сотрудничество между Средним Уралом и Китаем началось в 1991 г., когда было подписано Соглашение об установлении побратимских отношений между Свердловской областью и г. Харбином (КНР) и Протокол о торгово-экономическом сотрудничестве. На сегодняшний день Свердловской областью подписаны следующие двусторонние документы: Меморандум о сотрудничестве между Свердловской областью и городом Харбином, Соглашение о сотрудничестве между Законодательным Собранием Свердловской области и постоянным комитетом собрания Народных представителей провинции Хэйлунцзян, Меморандум о взаимопонимании между Министерством международных и

Внешнеторговый оборот Среднего Урала и стран БРИКС, млн долл.

Таблица 3

\begin{tabular}{|c|c|c|c|c|c|c|c|c|c|c|}
\hline \multirow[b]{2}{*}{ Страна } & \multicolumn{2}{|c|}{2010 r. } & \multicolumn{2}{|c|}{2011 r. } & \multicolumn{2}{|c|}{2012 r. } & \multicolumn{2}{|c|}{2013 r. } & \multicolumn{2}{|c|}{2014 r. } \\
\hline & $\begin{array}{c}\text { млн } \\
\text { долл. }\end{array}$ & $\begin{array}{l}\text { В \% к } \\
\text { итогу }\end{array}$ & $\begin{array}{c}\text { млн } \\
\text { долл. }\end{array}$ & $\begin{array}{l}\text { В \% к } \\
\text { итогу }\end{array}$ & $\begin{array}{c}\text { млн } \\
\text { долл. }\end{array}$ & $\begin{array}{l}\text { В \% к } \\
\text { итогу }\end{array}$ & $\begin{array}{c}\text { млн } \\
\text { долл. }\end{array}$ & $\begin{array}{l}\text { В \% к } \\
\text { итогу }\end{array}$ & $\begin{array}{c}\text { млн } \\
\text { долл. }\end{array}$ & $\begin{array}{l}\text { В \% к } \\
\text { итогу }\end{array}$ \\
\hline \multicolumn{11}{|c|}{ Эксnорт } \\
\hline всего, в т. ч.: & 8589,7 & 100 & 8063,7 & 100 & 9078,7 & 100 & 7225,5 & 100 & 7672,9 & 100 \\
\hline Индия & 709,9 & 8,3 & 291,2 & 3,6 & 321,3 & 3,5 & 184,2 & 2,5 & 229,0 & 3,3 \\
\hline Китай & 257,6 & 2,9 & 199,3 & 2,5 & 142,4 & 1,6 & 113,1 & 1,6 & 183,2 & 1,3 \\
\hline Бразилия & $4,7^{* *}$ & 0,05 & $5,0^{* * *}$ & 0,05 & 5,7 & 0,05 & 14,1 & 0,2 & $10,0^{* * *}$ & 0,2 \\
\hline ЮАР & 2,7 & 0,02 & 2,6 & 0,03 & 5,3 & 0,05 & 2,4 & 0,02 & $3,0^{* * \star}$ & 0,05 \\
\hline \multicolumn{11}{|c|}{ Импорт } \\
\hline всего, в т. ч.: & 3094,1 & 100 & 3283,6 & 100 & 2878,4 & 100 & 2802,5 & 100 & 3063,1 & 100 \\
\hline Китай & 460,6 & 14,9 & 581,2 & 17,7 & 545,2 & 19,0 & 549,9 & 19,6 & 629,3 & 20,4 \\
\hline Индия & 19,8 & 0,6 & 23,4 & 0,7 & 27,2 & 1,0 & 15,4 & 0,6 & 30,0 & 1,0 \\
\hline Бразилия & $0,5^{* *}$ & 0,02 & $2,0^{* * *}$ & 0,07 & 3,3 & 0,1 & 1,9 & 0,05 & $1,5^{* * *}$ & 0,07 \\
\hline ЮАР & 22,1 & 0,7 & 23,3 & 0,7 & 31,5 & 1,1 & 22,9 & 0,7 & $17,0^{* * *}$ & 0,8 \\
\hline
\end{tabular}

* Министертство международных и внешнеэкономических связей Свердловской области [Электронный pecypc]. URL: http: //mvs.midural.ru/news; Федеральная таможенная служба. Уральское таможенное управление [Электронный ресурс]. URL: http://utu.customs.ru; Приволжское таможенное управление [Электронный ресурc]. URL: http://ptu.customs.ru. (дата обращения: 06.03.2015).

** Данные за 2009 г.

*** Оценка. Объемы по экспорту и импорту товаров участников ВЭД Свердловской области, независимо от места совершения ими таможенных операций (без энергетической таможни и без учета торговли с Республикой Беларусь и Республикой Казахстан), приведены по данным Уральского таможенного управления ФТС России. 
внешнеэкономических связей Свердловской области и Департаментом экономического сотрудничества и внешней торговли СиньцзянУйгурского автономного района КНР.

В рамках соглашения с Харбином в 2006 г. Первоуральский завод комплектных металлических конструкций «Кометкон» и Харбинское научно-производственное предприятие «Сы Хай» подписали договор о совместном производстве машин термической и плазменной резки. Данное событие стало результатом долгосрочной планомерной работы с харбинскими партнерами.

Другой пример успешного регионального сотрудничества - кооперация между «Уральским турбинным заводом» (УТЗ) и «Харбинским турбинным заводом» (ХТ3). На сегодняшний день в КНР работают более 60 уральских турбин.

Наряду с дальнейшим ростом объема внешнеторговых операций увеличивается и количество крупных совместных инвестиционных проектов с КНР, реализуемых на территории Свердловской области. Начало этому процессу было положено в начале ноября 2006 г. на Российской национальной выставке в Пекине, где предприятиями Свердловской области был подписан ряд контрактов. ЗАО «Автомобили и моторы Урала» (АМУР) подписало контракты с китайской автомобильной корпорацией «Джили» о совместной сборке легковых автомобилей эконом-класса и с корпорацией «Чжонсин» о сборке джипов. Однако в связи с изменениями в российском законодательстве, предусматривающими увеличение таможенных сборов за ввозимые автокомплектующие, проект был свернут.

Большой интерес к Свердловской области проявляют китайские строительные компании и предприятия строительной индустрии. ООО «Монолит» (г. Нижняя Тура) был заключен контракт с китайским партнером на поставку оборудования для производства керамического кирпича мощностью 30 млн шт. условного кирпича в год.

Установлена китайская линия по производству композитных алюминиевых фасадных систем на $\mathrm{OOO}$ «Завод композитных материалов» (г. Новоуральск).

Развивается авиационное сообщение с КНР. С 5 июля 2009 г. из международного аэропорта «Кольцово» г. Екатеринбурга осуществляются регулярные авиарейсы Екатеринбург - Пекин. На сегодняшний день силами авиакомпаний «Уральские авиалинии» и «Сибирь» выполняется 5 рейсов в неделю. С 4 февраля 2012 г. ави- акомпания «Уральские авиалинии» начала выполнять прямой рейс Екатеринбург - Харбин.

15 сентября 2011 г. в рамках визита китайской делегации во главе с вице-мэром г. Харбина Цзяо Юанчао состоялся Деловой форум между представителями деловых кругов Харбина и Свердловской области. В переговорах приняли участие 35 харбинских предприятий и организаций и более 50 от Свердловской области. По результатам проведенных переговоров были подписаны 2 протокола о намерениях: между Уральским государственным экономическим университетом и Управлением инвестиций г. Харбина и между Управлением по развитию физкультуры, спорта и туризма Администрации г. Екатеринбурга и Управлением спорта г. Харбина. Кроме того, достигнуты предварительные договоренности по сотрудничеству в области энергетики, лесопереработки, медицины.

Китайские предприятия все более активно участвуют в выставочно-ярмарочных мероприятиях, проводимых на территории Свердловской области. В частности, 29 ноября - 1 декабря 2011 г. в международном выставочном центре «Екатеринбург-экспо» состоялась выставка «Горное дело: оборудование. Спецтехника». В рамках данной выставки был организован коллективный стенд, на котором были представлены 30 харбинских предприятий и состоялась презентация г. Харбина.

До 2008 г. Средний Урал наращивал свой внешнеторговый оборот с Китаем, который достигал 778,3 млн долл. (экспорт составил 330,4 млн долл., а импорт - 448,0 млн долл.). Заметная тенденция во внешнеэкономических связях области с Китаем - это рост импорта из Китая - с 259,6 млн в 2007 г. до 545,2 млн долл. в 2013 г.

Из Свердловской области в Китай в 2012 г. основном поставлялась минеральная продукция $(32,4 \%)$, в том числе штукатурные материалы $-18,2 \%$, шлаками, золой $-4,2 \%$. В значительных объемах поставлялись металлы и изделия из них (27,6\%), в том числе черные металлы - 11,6 \%, алюминий и изделия из них - 9,6 \%, металлокерамика - 6,4 \%. Заметную долю занимают поставки химической продукции (26,6 \%), в том числе продукты неорганической химии - $25 \%$, органические химические соединения - 1,6\%. На машиностроительную продукцию приходилось всего 12,9 \%, в том числе 9,2\% - механическое оборудование, 1,6 \% - электрическое оборудование, $2,1 \%$ - оптические аппараты. 
Из КНР на Средний Урал в основном поставлялась машиностроительная продукция - (34,1 \%), из них 16,4 \% - механическое оборудование, $12 \%$ - электрическое оборудование, 5,7 \% - средства наземного транспорта. На металлы и изделия из них приходилось 28,5 \% всех поставок, в том числе черные металлы 7,7 \% и изделия из них 10,2 \%, на прочие изделия из недрагоценных металлов - 7,7 \%, на ножевые изделия и инструменты $-2,9 \%$. На химическую продукцию приходилось 9,9 \% китайского импорта, в том числе пластмасса и изделия из нее $-5,2 \%$, резина и изделия из нее $-1,9 \%$, продуктами неорганической химии $-1,6 \%$, органическими химическими соединениями $-1,2 \%$. На текстильную продукцию приходилось 6,3 \%, в том числе на одежду из текстиля $-3,3$ \%, трикотажные вязаные изделия и прочие текстильные изделия по 1,5\%. Прочие товары - 5,8 \%, среди них игрушки $3,4 \%$, мебель - 2,4 \%; изделия из камня, гипса и керамические изделия -3 \%; штукатурные материалы - 1,2 \%.

Внешнеторговые связи и отношения со странами БРИКС Урал осуществляет по разным направлениям. Это, прежде всего, производственное сотрудничество в нефтегазовой сфере. Так, «Газпром» (РФ) и Китайская национальная нефтегазовая компания (CNPC) подписали в мае 2014 г. 30-летний контракт на строительство трубопровода «Сила Сибири» протяженностью 4 тыс. км - крупнейшего инфраструктурного проекта российского ТЭК с поставкой в КНР в 2018 г. до 38 млрд $\mathrm{M}^{3}$ газа в год по так называемому «восточному маршруту» (его релизация началась в сентябре 2014 г., совокупная стоимость контракта 400 млрд долл.) и меморандум (09.11.2014 г. на саммите АТЭС в Китае) о строительстве газопровода «Алтай» (по «западному маршруту» - Новый Уренгой - Горно-Алтайск и далее в Китай) протяженностью 2,6 тыс. км, диаметр трубы 1420 мм, объемы экспорта по нему могут вырасти с проектных 30 млрд м $^{3}$ до 100 млрд $\mathrm{M}^{3}$ в год (при прокладке второй и третьей веток газопровода). Это и пуск в эксплуацию нефтетрубопровода «ВСТО» (Восточная Сибирь - Тихий океан), обеспечивающий потребности стран Юго-Восточной Азии, и прежде всего, Китая в энергоносителях.

Ценность проекта «Сила Сибири» для Урала в том, что трубы для магистрального газопровода поставит в 2015 г. Челябинский трубопрокатный завод. В целом, сам проект потребует порядка 2,6 млн т стальных труб, в то время как отечественное производство трубной продукции в 2014 г. достигло 11,5 млн т, из которых на экспорт было поставлено 0,9 млн т. При этом Россия еще зависит от импорта стальных труб, его объем в 2014 г. составил 0,670 млн т [12, с. 48].

Говоря об импортозамещении, следует указать на тот непреложный факт, что большинство предприятий, в том числе и Уральского региона, осуществляющих импортные закупки, при всем их желании «закупать российское» не в состоянии, поскольку нужных машин, оборудования, транспортных средств, а порой сырья и материалов для их производства на территории страны недостаточно или они физически отсутствуют, многие из даже ранее функционировших производств были просто ликвидированы в лихие 1990-е, поскольку претворялся тезис «Запад все поставит», а следовательно, нет смысла тратить на новые разработки дополнительные ресурсы. Это привело к тому, что доля предприятий в отраслях, столкнувшихся с отсутствием отечественных аналогов оборудования и сырья составила (на начало 2015 г.) в черной металлургии России 76 \%, в цветной металлургии $-75 \%$, в машиностроении - $59 \%$, в леспроме и легпроме - по $72 \%$, в химпроме - $72 \%$, в пищепроме $-68 \%$, в производстве стройматериалов - 22 \% [13, с. 41]. Это вынуждает предприятия регионов использовать имеющиеся производственные мощности и переориентировать импортные поставки на страны Юго-Восточной Азии. В частности, на саммите АТЭС (Китай, 09.11.2014 г.) подписан меморандум о взаимопонимании между «Газпромом» и Китайской национальной шельфовой нефтяной корпорацией, а также рамочные соглашения между компанией «Роснефть» и CNPC в приобретении компанией «China National Oil and Gas Exploration and Development» 10-процентной доли участия в «Ванкорнефть», а также рамочное соглашение о кредитных линиях между Сбербанком РФ и экспортно-импортным банком Китая и соглашение о кредите покупателю между этими институтами; это и соглашение о сотрудничестве между Сбербанком и Китайской компанией страхования экспортных кредитов и соглашение между территориальной генерирующей компанией № 2 и компанией «Хуадянь» о реализации инвестиционных энергетических проектов в Архангельской области.

Стороны также скрепили подписями техническое соглашение по вопросам временного изменения пункта поставки на период 20152017 гг. по долгосрочному контракту куплипродажи сырой нефти от 21 июня 2013 г. на условиях предоплаты в рамках соглашения между правительствами двух стран, а также 
соглашение между «РусГидро» и корпорацией «Санься» о совместном финансировании, строительстве и эксплуатации гидроэлектростанций на Дальнем Востоке, соглашение между «РусГидро» и компанией «Power China» о coтрудничестве в области строительства гидроаккумулирующих станций и ряд других.

Подписаны три контракта между «Евроцементгрупп» и «Синома интернэшнл ЦДРИ» на поставку оборудования; соглашение о сотрудничестве между банком ВТБ и «Huawei Technologies»; меморандум о взаимопонимании между Внешэкономбанком, ВЭБ Азия, агентством по ипотечному жилищному кредитованию и государственным банком развития Китая ${ }^{1}$.

Китайские банки готовы профинансировать и проект «Ямал СПГ» на сумму более 10 млрд долл., предполагающий строительство завода мощностью 16,5 млн т СПГ в год на ресурсной базе Южно-Тамбейского месторождения. Разведанные и вероятные запасы месторождения по стандартам PRMS составляют 927 млрд м $^{3}$ газа. Акционерами проекта являются «НОВАТЭК» (РФ) - 60 \%, «Total» (Франция) 20 \% и CNPC (Китай) - 20 \%. Для привлечения инвестиций в проект обсуждается продажа китайским и индийским компаниям доли в «Ямал СПГ» в размере $9 \%$. Однако введение санкций со стороны США и ЕС, в том числе и в отношении «НОВАТЭК» (контролируемого А. Тимченко), сдерживают потенциальных инвесторов, и это притом, что уже законтрактовано 100 \% продукции СПГ: 27 \% на Китай, страны АТP - 36 \%. Тем не менее, через «Газпромэкспорт» уже было продано около 3 млн т на индийский рынок. Президент РФ В. В. Путин обещал поддержать данный проект. ${ }^{2}$

Реализация данных проектов позволит стимулировать развитие, освоить малообжитые, удаленные, северные и арктические районы России, Приполярного и Юга Урала, Западной и Восточной Сибири, Дальнего Востока и Приморского края.

Активизируются внешнеэкономические связи и промышленное сотрудничество РФ с Федеративной Республикой Индия. Внешнеторговый оборот с Индией в 2014 г. составил 11 млрд долл., против 10 млрд в 2013 г. и 5 млрд долл. в 1991 г. Тем не менее РФ и Индия на-

\footnotetext{
${ }^{1}$ РФ и КНР подписали меморандум о поставках газа по «западному маршруту» [Электронный ресурc]. URL: http:// ria.ru/east/ 20141109. (дата обращения: 11.11.2014).

2 Китай профинансирует «Ямал СПГ» на \$10 млрд [Электронный pecypc]. URL: http://finance.rambler.ru/news/ economics/153310619. (Дата обращенния: 07.11.2014).
}

мерены довести внешнеторговый оборот к 2025 г. до 30 млрд долл. Не малая роль в этом росте будет отводиться регионам России. Так, Средний Урал наладил более тесное сотрудничество с Индией с 1947 г. - года провозглашения Республики Индия.

Среди отечественных предприятий наибольший вклад в развитие индийской промышленности внесли и гиганты еще «социндустрии», например, Уральский завод тяжелого машиностроения (УЗТМ), участвовавший по заказу Индийской корпорации по атомной энергетике в изготовлении двух полярных кранов для блока № 1 индийской АЭС «Куданкулам». Всего УЗТМ (с 1956 г.) поставил для металлургических предприятий Индии более 160 наименований машиностроительной продукции. В феврале 2007 г. машиностроительной корпорацией «Уралмаш» совместно с ГО «Тяжпромэкспорт» был заключен контракт на строительство аглофабрики металлургического завода Визакхапатнам. Подписаны контракты со всеми заводами государственной металлургической корпорации САИЛ (SAIL) на поставки различных запчастей к металлургическому оборудованию (доменные печи, машины непрерывного литья заготовок, дробилок, шагающих экскаваторов, агломашины и др.), уже действуют контракты на поставку прокатных валков на все вышеуказанные металлургические заводы. Подписан контракт на поставку вагоноопрокидывателя (2 шт.) на металлургический завод Визакхапатнам.

Активно сотрудничает с индийскими партнерами ОАО Научно-производственная корпорация «Уралвагонзавод», и не только в сфере военно-технического сотрудничества (танки Т-72 и Т-90). Уральским конструкторским бюро вагоностроения совместно с индийскими компаниями ведутся разработки перспективных образцов железнодорожных вагонов для индийских железных дорог. На протяжении многих лет «Уральский оптико-механический завод» сотрудничает с корпорацией «Хиндустан Аэронавтикс Лимитед» («Hindustan Aeronautics Limited»), а «Уральский завод гражданской авиации» выполняет контракты по ремонту индийской авиатехники.

В 2011 г. Научно-исследовательский институт машиностроения осуществил авторское сопровождение монтажных работ и испытаний поставленного ранее в Космический центр HSAR ISRO криогенного оборудования для испытательных стендов жидкостных ракетных двигателей и двигательных установок. Сумма контракта превысила 500 тыс. долл. 
Уральские предприятия активно сотрудничают с индийскими партнерами в сфере энергетики. Так, по соглашению между «Уралэлектротяжмаш» и индийской фирмой «Тери» осуществляются поставки и монтаж оборудования для электростанции. ЗАО «Энергомаш (Сысерть) - Уралгидромаш» произвел поставку электродвигателей для АЭС «Куданкулам» (а в начале 2015 г. Россия передала Индии в техническую эксплуатацию 1-й энергоблок данной АЭС), а также запасных частей к насосному оборудованию для Бхилайского сталелитейного завода. В настоящее время предприятие заключило контракты на поставку насосного оборудования и запасных частей к нему со сталелитейным заводом Бокаро. Кроме того, экспорт высоковольтной аппаратуры в Индию ведет $3 \mathrm{AO}$ «Энергомаш (Екатеринбург) - «Уралэлектротяжмаш»; поставки гидравлического оборудования и насосных агрегатов - «Пневмостроймашина», запасные части к мембранному компрессору «Уральский компрессорный завод».

Крупным внешнеторговым партнером является ОАО «Ураласбест» (общий объем его экспорта в 2013 г. составил 132,2 млн долл., а в 2014 г. - 129,6 млн долл.), которое поставляет широкую гамму марок хризотил-асбеста для асбоцементной и асботехнической промышленности Индии.

Существенно расширились прямые внешнеэкономические связи между предприятиями Среднего Урала и Республикой Индия с 1991 г., когда область открыла свой внутренний рынок для инопартнеров, а в 1992 г., провела первую выставку индийских товаров.

Расширяется сотрудничество среднего Урала с Индией и в сфере образования. Так, Уральский государственный экономический университет осуществляет сотрудничество с индийской компанией «Аптек Вордвайд» («Aptech Worldwide»), в рамках которого с 2007 г. на базе УрГЭУ функционирует международный образовательный центр «Арена мультимедиа» («Arena Multimedia»). Центр готовит специалистов по инновационным методикам в области информационных технологий по программе «Компьютерная графика и мультимедийные технологии» в соответствии с международными стандартами Aptech. Корпорация «Aptech» имеет сеть из 3240 центров в 52 странах мира и предлагает получить образование в области мультимедиа технологий. На сегодняшний день «Арена Мультимедиа - УрГЭУ» занимает лидирующие позиции на рынке образовательных услуг в сфере компьютерной графики и мультимедиа в Екатеринбурге и Свердловской области благодаря уникальности международных образовательных программ, особому подходу к разработке учебнометодического обеспечения курсов, привлечению к работе высококвалифицированных сотрудников, прошедших международную аккредитацию. В 2012 г. УрГЭУ заключил договор с «Аптек Инглиш Ленинг Академии» на программы изучения английского языка, реализуемые при сотрудничестве с Кембриджским университетом ${ }^{1}$.

Реализация разнообразных проектов позволила Свердловской области нарастить внешнеторговый оборот с Индией со 135,6 млн долл. в 2006 г. до 348,5 млн долл. в 2012 г., но снизила его в 2013 г. до 199,8 млн долл. и 260 млн в 2014 г. При этом экспорт из области составил 260 млн, а импорт - 30 млн долл. В 2012-2014 гг. до 50 \% экспорта области в Индию поставлялась машиностроительная продукция, в том числе: средства наземного транспорта (42\%), механическое оборудование (5\%), фото- и оптическое оборудование (2 \%), электрическое оборудование (1\%). На металлы и изделия из них приходилось 22 \%, в том числе: черные металлы $18 \%$, алюминий и изделия из него $-3 \%$, металлокерамика $-1 \%$, штукатурные материалы $-8 \%$, химическая продукция $-2 \%$, продукты неорганической химии и смешанные химические продукты - по $1 \%$.

До 61 \% импорта из Индии на Средний Урал в 2012-2014 гг. составила машиностроительная продукция, в том числе: электрическое оборудование - 50 \%, фото- и оптическое оборудование - $9 \%$, механическое оборудование $2 \%$. На металлы и изделия из них приходилось 25 \% импорта, в том числе: изделия из черных металлов - $10 \%$, инструменты из недрагоценных металлов - 10 \%; на продовольственную продукцию $-6 \%$, в том числе: $5 \%$ - на шеллак и $1 \%$ - на продукты переработки овощей и плодов; на штукатурные материалы - $1 \%$, на резину и изделия из нее $-4 \%$; на ковры $-1 \%$, остальное - фармацевтическая продукция.

Бразилия - еще один растущий партнер БРИКС. На его долю приходится $25 \%$ бразильского экспорта, в том числе: Китай -46 млрд долл. в 2013 г., Индия - 1,3 млрд, Россия - почти 3 млрд, ЮАР - 1,8 млрд долл. Доля Среднего Урала во внешнеэкономических связях с Бразилией на порядок ниже, чем России.

\footnotetext{
${ }^{1}$ Министертство международных и внешнеэкономических связей Свердловской области [Электронный ресурс]. URL: //http: //mvs.midural.ru/news.
} 
Так, экспорт в Бразилию из Свердловской области вырос с 4,9 млн долл в 2008 г. до 14,1 млн долл. в 2013 г. В основном поставлялись: химическая продукция (35 \% - всё продукты неорганической химии), металлы и изделия из них -65 \% (в том числе черные металлы и изделия из них, ферросплавы - 20 \%, медь $-3 \%$, алюминий $-42 \%)$. По импорту в область поступали: машиностроительная продукция - 47 \% (в том числе бульдозеры и запчасти к ним), продукция химии $-25 \%$ (из них неорганические химические продукты $23 \%$, шины - 2 \%), металлы и изделия из них -20 \% (изделия из черных металлов, инструменты), древесина и изделия из нее $-4 \%$, пищевая продукция - 1 \% (в основном фрукты), прочие товары $-4 \%$ (в основном керамические изделия).

Расширяется участие стран БРИКС в международной военно-промышленной выставке (очередная X «Russia Arm Expo - 2015» пройдет 9-12 сентября 2015 г. в г. Нижний Тагил, Свердловская область) и в Иннопром. КНР участвует в качестве официального партнера в международной промышленной выставке Иннопром-2015 (г. Екатеринбург, с 8-го по 11 июля 2015 г.) «Производственная эффективность» (Industrial efficiency), где будет проведено 5 выставок по следующим тематическим направлениям: машиностроение, энергоэффективность, технологии для города, оптика и лазеры, индустриальная автоматизация. Сделано приглашение для участия в ней Индии, Бразилии и ЮАР.

Для обеспечения внешнеэкономической деятельности страны БРИКС создают банковскую инфраструктуру, предполагающую осуществление торговли заинтересованных стран в национальной валюте (юанях и рублях), в так называемом безбарьерном варианте. В частности, «Газпромнефть» (РФ) в 2014 г. начала торговлю с КНР в юанях, а 29.12.2014 г. КНР запустила своповую торговлю на межбанковском валютном рынке парой юань - рубль.

Активным участником внешнеэкономических связей и отношений стран БРИКС становится Южный Урал. В частности, в Челябинской области при поддержке губернатора реализуется международный проект транспортнологического комплекса (ТЛК «Южноуральский»), который позволит организовать транспортный коридор от Урумчи (КНР) - Достык (Казахстан) до Карталы (РФ, юг Челябинской области) и далее по территории России в Европу, Среднюю Азию. ТЛК будет включать складское хозяйство $\left(82\right.$ тыс. $\left.\mathbf{M}^{2}\right)$, контейнерный терминал мощно- стью 700 TEU (twenty-foot equivalent unit - эквивалент двадцатифунтового контейнера) для доставки товаров (контейнеров) кратчайшим путем из Китая, проект которого был представлен еще в июне 2012 г. на саммите ШОС в Пекине, а в апреле 2014 г. к проекту подключилась российская Государственная транспортная лизинговая компания. Общий объем вложений - 6,8 млрд руб. Данный проект позволит разгрузить Транссиб и сократить сроки доставки грузов с 36 до 10 дней [14, с. 28-29].

Это и реализация проекта по строительству высокоскоростного железнодорожного пути Пекин - Москва (через Казахстан и РФ). Протяженность пути -7 тыс. км, стоимость проекта -242 млрд долл., время в пути - двое (вместо семи) суток. Стоимость российского участка Москва - Казань (770 км пути) составит свыше 1,1 трлн руб. [15, с. 35], и Казань Екатеринбург - еще столько же (и по протяженности и по цене). Далее предполагается продолжить магистраль через Челябинск, Казахстан и в КНР.

Реализация проекта по строительству высокоскоростной межгосударственной магистрали облегчается тем, что Китай уже имеет опыт их строительства, наработанный ранее с помощью технологий «Сименс» (ФРГ).

Уральские предприятия, и прежде всего «Мечел» (Челябинская область), могли бы участвовать в строительстве линий высокоскоростного движения, поскольку могут катать стометровые рельсы, с повышенной грузонапряженностью, ямея рельсобалочный стан мощностью в 1 млн т продукции в год, собранный еще в 2012 г.

Оренбургская область также наращивает свои усилия по расширению транспортного сотрудничества с КНР. Это касается строительства на территории области участка международной автотрассы Западная Европа - Западный Китай (протяженность трассы 8,5 тыс. км, в том числе по территории России - 2,2 тыс. км и Казахстана $-2,8$ тыс. км).

Ужесточение санкций развитых стран в отношении России сужает производственные возможности страны, оказывает свое негативное воздействие на качество жизни населения и прежде всего на продовольственную безопасность. В этой связи страны БРИКС оказались действенным средством и инструментом смягчения этих санкций, открыв новые, дополнительные для них возможности по расширению внешнеэкономических связей, проникновения и закрепления на российском, в том числе и уральском рынках сельхоз- и морепродукции, 
а также такой дефицитной для Урала продукции, как фрукты, овощи, цитрусовые, специи, кофе, мясо-молочная и иная, вино.

Южноафриканские, китайские, бразильские и индийские сельхозпроизводители уже выразили свою готовность и желание восполнить возникший пробел в данном сегменте внешнеэкономических связей. Если Китай уже осваивает региональные рынки России поставками своей сельхозпродукции, то делегация южноафриканских сельхозпроизводителей во главе с Чрезвычайным и Полномочным Послом ЮАР в РФ Мандиси Мпахлуа 15 ноября 2014 г. посетила Средний Урал и обсудила возможность налаживания прямых поставок на уральский рынок своих фруктов, цитрусовых, морепродуктов и рыбы, специй, вина. Кроме того, Средний Урал готов расширить сотрудничество с ЮАР в горнорудной, металлургической и машиностроительной промышленности. ЮАР, в свою очередь, пригласила на международный железнодорожный форум (июнь 2015 г.) четыре компании Среднего Урала. В 2011 г. из Свердловской области в ЮАР поставлялись металлы и изделия из них (97 \% всего экспорта), в том числе алюминий и изделия из них (88 \%), черные металлы (9 \%). На продукты неорганической химии приходилось - $2 \%$, на древесину $-1 \%$. Из ЮАР в Свердловскую область поставлялись продукты неорганической химии - до 97 \% всех поставок, штукатурные материалы - 2 \%. В 2012-2014 гг. эти тенденция сохранилась. Так, в 2012 г. Средний Урал поставил в ЮАР металлы и изделия из них, в том числе черные металлы (52 \% всех поставок) и алюминий и изделия из них (48 \%). Из ЮАР на Средний Урал поставлялись продукты неорганической химии (98\%), механическое оборудование - до $1 \%$. Сам внешнеторговый оборот области с ЮАР достиг в 2013 г. 25,3 млн долл., в том числе экспорт $-2,4$ млн, импорт $-22,9$ млн долл., в основном фрукты и вина (внешнеторговый оборот РФ и ЮАР в 2013 г. составил
987 млн долл.), что ниже уровня 2008 г. $-52,4$ млн долл.

\section{Заключение}

Результаты проведенного исследования показывают, что даже в условиях финансовых, экономических, политических и иных санкций и ограничений со стороны западных стран, в условиях падения основных макроэкономических показателей за 2014 г. в стране регионы Урала продолжают наращивать объемы экспорта своей продукции. Из 100 ведущих экспортеров Урала (с объемами экспорта свыше 3 млн долл. в год) лишь 42 предприятия снизили объемы экспорта, а 58 - нарастили его. Причем отмечается даже некоторый рост внешней торговли с развитыми странами, и прежде всего с США. В то же время отчетливо прослеживается тенденция сокращения объемов экспорта и импорта с Украиной (в 2 раза за 2014 г.), а за два последние два года - почти в 3 раза. При этом растут объемы экспорта и (особенно) импорта со странами Юго-Восточной Азии, и прежде всего с Китаем и Индией. Курс на импортозамещение предполагает существенную трансформацию отечественной экономики, ее большую ориентацию на внутренний спрос и производство, поскольку почти в 3/4 в отраслей черной и цветной металлургии, леспроме, химпроме, легпроме, пищепроме, машиностроении отсутствуют отечественные аналоги оборудования и сырья. Все это заставляет предприятия Урала активизировать свое участие в разработке и реализации импортозамещающей продукции, увязывая национальные и региональные интересы промышленной политики с теми возможностями, которые дает развитие внешнеэкономических связей регионов с развитыми и развивающимися странами и открывает новые возможности и горизонты сотрудничества в рамках БРИКС и вне их, с доведением доли АТР во внешнеторговом обороте России с 25 до $40 \%$.

\section{Благодарность}

Статья подготовлена при финансовой поддержке гранта РГНФ № 15-02-00587a.

\section{Список источников}

1. Устинов И.Н. Мировая торговля. Статистическо-энциклопедический справочни. - М.: ЗАО «Издательство “Экономика"», 2002. - 848 с.

2. Словарь иностранных слов / Под ред. И. В. Лехина и проф. Ф. Н. Петрова; 3-е перераб. и доп. изд. -М.: Госиздательство иностранных и национальных словарей, 1949. - 806 с.

3. Проблемы международного сотрудничества в рамках ШОС : сб. науч. тр. - Екатернибург: Институт экономики УpO PAH, 2011. - $258 \mathrm{c}$.

4. Аганбегян А.Г. Об условиях и факторах социально-экономического развития России // Журнал экономической теории. - 2014. — № 4. - С. 71-82.

5. Сорокин Д. Е. Экономическая теория, экономическая реальность и экономическая политика // Журнал экономической теории. - 2014. - № 4. - С. 25-39. 
6. Ивантер А. Условно уценили // Эксперт. - 2015. - № 10 (936) (2-8 марта). - С. 13-17.

7. Цветков В. А., Байдурин М.С. К вопросу осмысления новых теоретических подходов к системе управления экономическими интеграционными процессами на макроуровне // Журнал экономической теории. — 2014. — № 4. - С. 200-211.

8. Масленников М. И. Металлургия Урала. Проблемы и реальные возможности технологической модернизации и инновационного развития. - Екатеринбург: Институт экономики УрО РАН, 2012. - 220 с.

9. Жога Г. Конец времени // Эксперт-Урал. - 2014. — № 14 (31 март. - 6 апр.). - С. 15-20.

10. Масленников М. И. Пути наращивания экспортного потенциала и внешнеэкономической экспансии России и регионов Урала. - Екатеринбург: ИЭ УрО РАН, 2008. - 218 с.

11. Масленников М. И. Управление развитием внешнеэкономических связей регионов // Проблемы региональной экономики. - 2014. - № 3-4. - С. 32-44.

12. Кудияров С. Равнение на «Силу Сибири» // Эксперт. - 2015. - № 16 (13-19 апреля). - С. 48.

13. Цухло С. Как победить засилье импорта // Эксперт. - 2015. - № 12 (938) (16-22 марта). - С. 40-42.

14. Белоусов А. От Поднебесной до новой экономики // Эксперт-Урал. - 2014. — № 45(622) (3-9 нояб.). - С. 28-29.

15. Мерешко Н. Дешевая китайская скорость // Эксперт. - 2015. - № 6 (2-8 февр.). - С. 32-35.

\section{Информация об авторе}

Масленников Михаил Иванович (Екатеринбург, Россия) - доктор экономических наук, профессор, ведущий научный сотрудник, Институт экономики Уральского отделения Российской академии наук (620014, г. Екатеринбург, ул. Московская, 29, e-mail: mim1943@ mail.ru).

\section{I. Maslennikov}

\section{Problems of Foreign Economic Relations Development of Ural Regions with BRICS Countries}

In the article, the basic vocabulary of BRICS countries, its regional tendencies of business development, and its share taken in the foreign-economic activity are analyzed. Contribution of different foreign trade fields of regions into economic development is revealed. Indicators of development levels of external economic links are reviewed. Alternative options of the foreign trade development, expenses and benefits from its reorientation, and the reason of low indicators of development of foreign trade activity of the Ural regions with BRICS countries are evaluated, and measures for their improvement and development are offered. The mechanism and tools of stimulation of foreign economic relations development of regions with BRICS countries are investigated. The internal and external motives and incentives of expansion of these relations are examined. The factors influencing the regional markets development and revealing multidirectional tendencies in activities of business, government, society for development of foreign economic relations of the Ural regions with BRICS countries, and first of all with Brazil, India, China and the Republic of South Africa are investigated. The export-import features of the foreign trade operations with these countries, and also possible ways and the directions of expansion of the prognostics of foreign economic relations in the conditions of toughening and restriction of similar operations and financial sources from the developed countries, first of all the USA and EU countries are represented.

Author examines the reasons and scenario, problems and difficulties for the country and the Ural regions in refocusing of international economic relation from Western Europe to the South-East Asia countries. Real opportunities of participation of regions of the country in the import substitution and development of own resource and production base are analyzed. The research is focused on analysis of international economic relations of the Middle-Ural enterprises with BRICS countries, on identification of causes and effects for enterprises of the old industrial region of reduction of export-import transactions on both developed, and emergent markets in the conditions of toughening and instability of environment in the national and world financial markets.

Keywords: BRICS, international economic relations, Ural regions

\section{Acknowledgement}

The article has beed prepared with the support of grant of Russian Humanitarian Science Foundation No. 15-02-00587a.

\section{References}

1. Ustinov, I. N. Mirovayaa torgovlya. Statistichesko-entsiklopedicheskiy spravochnik [World trade: statistical-encyclopedia reference book]. Moscow Economika Publ., 848.

2. Lekhin, I. V. \& Petrov, F. N. (Eds). (1949). Slovar inostrannykh slov [Vocabulary of foreign words]. 3d revised and enlarged edition. Moscow: Gosizdatelstvo inostrannykh i natsionalnykh slovarey [State publishing house of foreign and national dictionaries], 806.

3. Problemy mezhdunarodnogo sotrudnichestva v ramkakh ShOS: sb. nauch. tr. [Problems of international collaboration in frame SCO: collection scientific works]. Yekaterinburg: Insititut ekonomiki UrO RAN [Institute of Economics, UB RAS], 258.

4. Aganbegyan, A. G. (2014). Ob usloviyakh i faktorakh sostialno-ekonomicheskogo razvitiya Rossii [On the conditions and factors of socio-economic development of Russia]. Zhurnal ekonomicheskoy teorii [Journal of economic theory], 4, 71-82.

5. Sorokin, D. Ye. (2014). Ekonomicheskaya teoriya, ekonomicheskaya realnost i ekonomicheskaya politika [Economic theory, economic policy and economic reality]. Zhurnal ekonomicheskoy teorii [Journal of economic theory], 4, 25-39.

6. Ivanter, A. (2015). Uslovno utsenili [Conditionally reduced the price]. Ekspert [Expert], 10 (936), (March, 2-8), 13-17.

7. Tsvetkov, V. A. \& Baydurin, M. S. (2014). K voprosu osmysleniya novykh teoreticheskikh pokhodov k sisteme upravleniya ekonomicheskimi intergatsionnymi protsessami na makrourovne [On the question of interpretation of new theoretical approaches to the management of economic integration processes at the macro level]. Zhurnal ekonomicheskoy teorii [Journal of economic theory], 4, 200-211.

8. Maslennikov, M. I. (2012). Metallurgiya Urala. Problemy $i$ realnyye vozmozhnosti tekhnologicheskoy modernizatsii $i$ innovatsionnogo razvitiya [Metallurgy of the Ural: problems and real opportunity of technological modernization and innovation development]. Yekaterinburg: Institut Ekonomiki UrO RAN [Institute of Economics, UB RAS], 220. 
9. Zhoga, G. (2014). Konets vremeni [Finish of time]. Ekspert-Ural [Expert-Ural], 14, (March, 31 - April, 6), 15-20.

10. Maslennikov, M. I. (2008). Puti narashchivaniya eksportnogo potentsiala i vneshneekonomicheskoy ekspansii Rossii i regionov Urala [Ways to grow export potential and international economic expansion of Russia and regions of the Ural]. Yekaterinburg, IE UrO RAN [IE, UB RAS], 218.

11. Maslennikov, M. I. (2014). Upravlenie razvitiem vneshneekonomicheskikh svyazey regionov [Management of the development international economic relation of regions]. Problemy regionalnoy ekonomiki [Problems of regional economic], 3-4, 32-44.

12. Kudiyarov, S. (2015). Ravnenie na «Silu Sibiri» [Look up to «Force of Siberia»]. Ekspert [Expert], 16, (April, 13-19), 48.

13. Tsukhlo, S. (2015). Kak pobedit zasilye importa [How to win domination of import]. Ekspert [Expert], 12(938), (March, 16-22), 40-42.

14. Belousov, A. (2014). Ot Podnebesnoy do novoy ekonomiki [From the Heavenly Empire to new economics]. Ekspert-Ural [Expert-Ural], 45(622), (Novemebr, 3-9), 28-29.

15. Mereshko, N. (2015). Deshyovaya kitayskaya skorost [Cheap chine’s of speed]. Ekspert [Expert], 6, (2-8 February), 32-35.

\section{Information about the author}

Maslennikov Mikhail Ivanovich (Yekaterinburg, Russia) - Doctor of Economics, Professor, the Institute of Economics of the Ural Branch of the Russian Academy of Sciences (29, Moskovskaya St., 620014 Yekaterinburg, Russia; e-mail: mim1943@ mail.ru). 